\title{
Synthesis, characterization, and in vitro antimicrobial investigation of novel pyran derivatives based on 8-hydroxyquinoline
}

\author{
Mohamed Rbaa ${ }^{1}$, Abdelhadi Hichar ${ }^{2}$, Omar Bazdi ${ }^{2}$, Younes Lakhrissi ${ }^{1}$, Khadija Ounine $^{2}$ and Brahim Lakhrissi ${ }^{*}$ (D)
}

\begin{abstract}
Background: 8-Hydroxyquinoline derivatives are known for their extensive applications in the field of analytical chemistry and separation techniques; their complexes with transition metals also exhibit antibacterial and antifungal activity.

Results: In the present study, we synthesized a new series of pyranoquinoline derivatives and evaluated their antibacterial activities. The structures of the synthesized compounds were characterized by Fourier transform infrared (FT-IR), hydrogen-1 nuclear magnetic resonance, carbon-13 nuclear magnetic resonance, and elemental analysis. All the prepared compounds were evaluated in vitro as antimicrobial agents against Gram-positive and Gram-negative bacterial strains (Escherichia coli (ATCC35218), Staphylococcus aureus (ATCC29213), Vibrio parahaemolyticus (ATCC17802), and Pseudomonas aeruginosa (ATCC27853)). The screening test was determined by using the standard protocol of disc diffusion method (DDM).

Conclusion: We have synthesized new pyranic compounds bearing an 8-hydroxyquinoline moiety on their structure. The preliminary screening results showed that all the tested compounds have a remarkable inhibitory effect on the growth of the majority of the tested bacterial strains compared to the standard antibiotic (penicillin $\mathrm{G})$, and the chlorinated compound $\left(\mathrm{Q}_{1}\right)$ is more active against Gram-positive bacteria than Gram-negative bacteria such as the Staphylococcus aureus strain which is the most sensitive. Gram-positive bacteria are responsible for a wide range of infectious diseases, and rising resistance in this group is causing increasing concern. Thus, this study develops novel heterocyclic compound derivatives of 8-hydroxyquinoline that have demonstrated good antibacterial activity against Gram-positive bacteria.
\end{abstract}

Keywords: Quinoline, Synthesis, Characterization, Antibacterial activity, In vitro, Bacterial strains

\section{Background}

Microbes are essential microorganisms which are needed for both humans and environment because of their vital role in almost all ecosystems. However, they can also be the cause of many infectious diseases [1], Some microorganisms like bacteria and yeasts can be pathogenic and cause diseases in humans, plants, or animals while pathogenic bacteria are responsible for several epidemic and pandemic diseases [2]. Therefore, the search for an anti-infectious substance has become a public health

\footnotetext{
* Correspondence: b.lakhrissi2012@gmail.com; brahim.lakhrissi@uit.ac.ma 'Laboratory of Agro-resources, Polymers and Process Engineering, Department of Chemistry, Faculty of Sciences, Ibn Tofaill University, PO Box 133, 14000 Kenitra, Morocco

Full list of author information is available at the end of the article
}

problem. From a series of observations and works by many researchers including Pasteur, Joubert, Duchesne, and Fleming, this quest has consequently led to the discovery of antibiotics [3].

This widespread use of antibiotics has also led in its turn to the appearance of strains of pathogenic microorganisms resistant to these drugs, together with the emergence of uncommon infections [4]. that compromise treatments with existing drugs. This phenomenon leads to an increase in morbidity and mortality [5]. In the face of these new barriers brought about by the use of available antimicrobials, it is essential to look for new, effective, and broad-spectrum substances.

On the other hand, the 8-hydroxyquinoline derivatives have long been known because of their widespread 
application in the field of analytical chemistry and separation techniques [6], since it plays a very important role for the extraction of metal ions; their complexes with various metal ions have been reported to be active against certain bacteria and fungi and whose power is proportional to their ionic chelation due to their lipid solubility [7]. On the other hand, some derivatives have also been reported as potential inhibitors of HIV-1 integrase. They have also been used as powerful agents for neuroprotection against Alzheimer's disease, Parkinson's disease, and other neurodegenerative diseases [8]. A work on antibacterial activity has recently been carried out in our laboratory on 8-hydroxyquinoline derivatives; these compounds have shown a good activity against Gram-positive and Gram-negative bacteria such as Escherichia coli, Staphylococcus aureus, Enterobacter ludwigii, and Bacillus subtilis [9].

The preparation of pyranoquinoline derivatives consists in reacting equimolar amounts of 8hydroxyquinoline, 4-alkylbenzaldehyde, and methyl-2cyanoacetate in pure ethanol in the presence of calcium bicarbonate under magnetic stirring during $24 \mathrm{~h}$.

The objective of this work is to synthesize and evaluate the antibacterial activity against Gram-positive and Gram-negative bacterial strains of new pyranoquinoline derivatives.

\section{Materials and method}

\subsection{Chemicals and apparatus}

The reagents and solvents used in this study were purchased from Acros or Sigma-Aldrich companies. All tests were done on a Kofler bench (infrared (IR)). Melting points were determined on a Banc Kofler apparatus and are uncorrected. The recording of nuclear magnetic resonance spectra was performed on a Bruker Advanced $300 \mathrm{WB}$ at $300 \mathrm{MHz}$ for solutions in $\mathrm{Me}_{2} \mathrm{SO}-\mathrm{d}_{6}$, and chemical shifts are given in $\delta_{\mathrm{ppm}}$ with reference to tetramethylsilane (TMS) as an internal standard. Infrared spectra were recorded in a FT-IR Nicolet 400D Spectrophotometer using potassium bromide $(\mathrm{KBr})$ pellets. The elemental composition (carbon, hydrogen and nitrogen) was determined on a Perkin-Elmer Model $240 \mathrm{CHN}$ Analyzer. The progress of the reaction is followed by thin-layer chromatography (TLC) of silica 60 F254 (E. Merck).

\subsection{Bacterial strains}

Four bacteria have been selected for this study to test the antibacterial activity of synthesized products. These bacteria are Escherichia coli that cause food poisoning and infections [10]; Staphylococcus aureus that causes life-threatening complications such as infection in blood [11], bones, or lungs; Pseudomonas aeruginosa is considered a human pathogen more often responsible for nosocomial infections [12]; and Vibrio parahaemolyticus, which represents a serious and global threat to human health [13]. The bacterial isolates Escherichia coli, Staphylococcus aureus, and Pseudomonas aeruginosa are of clinical origin. However, Vibrio parahaemolyticus is a major cause of food poisoning. They were all provided by the Laboratory of Nutrition, Health and Environment, Department of Biology, Faculty of Sciences, University Ibn Tofaïl - Kenitra, Morocco. Each bacterium was inoculated on the Ageller Mueller-Hinton culture medium.

\subsection{Culture medium and solvent}

The medium used in this study is Mueller-Hinton agar standardized by the World Health Organization (WHO) to determine the susceptibility of bacteria to antibiotics. The Mueller-Hinton agar medium composition is shown in Table 1. Dimethyl sulfoxide (DMSO) was used as a solvent to solubilize the tested compounds, and the physiological solution $(9 \mathrm{~g}$ of sodium chloride $(\mathrm{NaCl})$ in $1 \mathrm{~L}$ of distilled water) was used to regulate the physiological metabolisms of the bacteria under the experimental conditions (denaturing condition).

\section{Experimental part}

\subsection{Chemical synthesis and characterization (See Additional file 1)}

\subsubsection{General procedure for the synthesis of compounds}

A mixture of the substituted $p$-benzaldehyde (0.01 eq), methyl 2-cyanoacetate ( $0.01 \mathrm{eq})$, and calcium carbonate (0.01 eq) in absolute ethanol $(30 \mathrm{ml})$ was stirred at room temperature for $6 \mathrm{~h}$. To this mixture was added 8hydroxyquinoline (HQ) (0.01 eq), and the reaction mixture was refluxed under magnetic stirring for $18 \mathrm{~h}$. The reaction mixture was filtered while hot, and the filtrate was allowed to cool for 30 min until the expected product was precipitated. The formed solid was collected by filtration, washed with hexane, purified by silica column chromatography using a mixture of acetone/hexane (85: $15, \mathrm{v} / \mathrm{v})$, and then recrystallized from absolute ethanol to afford the desired compounds (Fig. 1).

The chemical structures, names, and abbreviations of the synthesized compounds are given in Table 2.

Table 1 Composition of Mueller-Hinton agar culture medium

\begin{tabular}{ll}
\hline Casein hydrolysate & $17.5 \mathrm{~g}$ \\
\hline Starch & $1.5 \mathrm{~g}$ \\
Agar & $10.0 \mathrm{~g}$ \\
Distilled water & $1000.0 \mathrm{ml}$ \\
Final pH & 7.4 \\
\hline
\end{tabular}



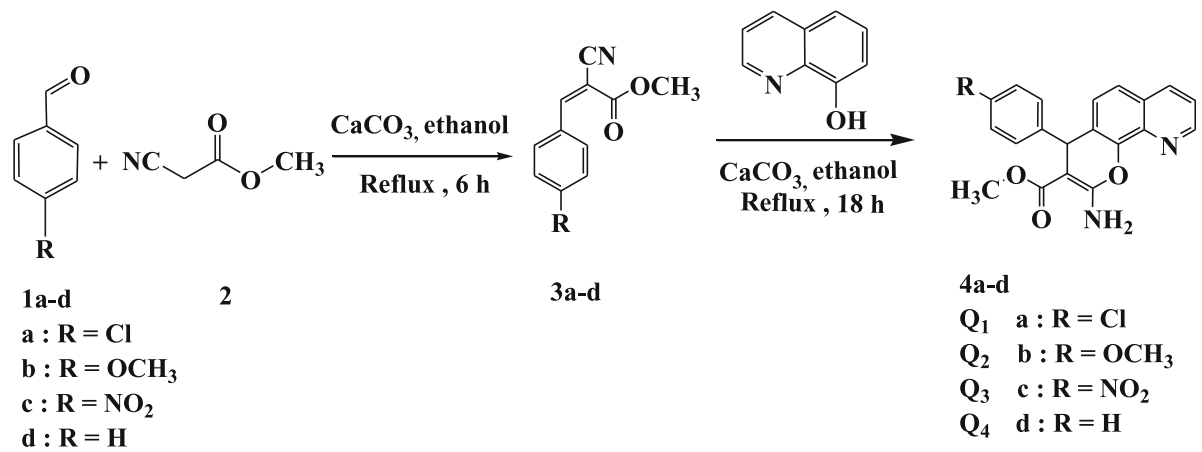

Fig. 1 Synthetic route for the preparation of pyranoquinoline derivatives

\subsection{Antibacterial test}

The antibacterial activity of our tested compounds was determined using the agar disc diffusion assay, while a 24-h bacterial culture was spread on the surface of the Mueller-Hinton agar plate. A disc of sterile $6-\mathrm{mm}$ filter paper was saturated with $10 \mu \mathrm{l}$ of solution of the studied compounds in dimethyl sulfoxide. After $1 \mathrm{~h}$ of diffusion, the Petri dishes were incubated at $37^{\circ} \mathrm{C}$ for $24 \mathrm{~h}$ and the diameter of the zone of inhibition was measured and compared with that of the penicillin $\mathrm{G}$ reference disc.

\section{Result}

4.1 Synthesis and spectral data

4.1.1 Synthesis of methyl 2-amino-4-(4-chlorophenyl)-4Hpyrano[3,2-h]quinoline-3-carboxylate $\left(Q_{1}\right)$

It was synthesized from 4-chlorobenzaldehyde with methyl 2-cyanoacetate and 8-hydroxyquinoline (HQ)

Table 2 Chemical structures, names, and abbreviations of the synthesized compounds

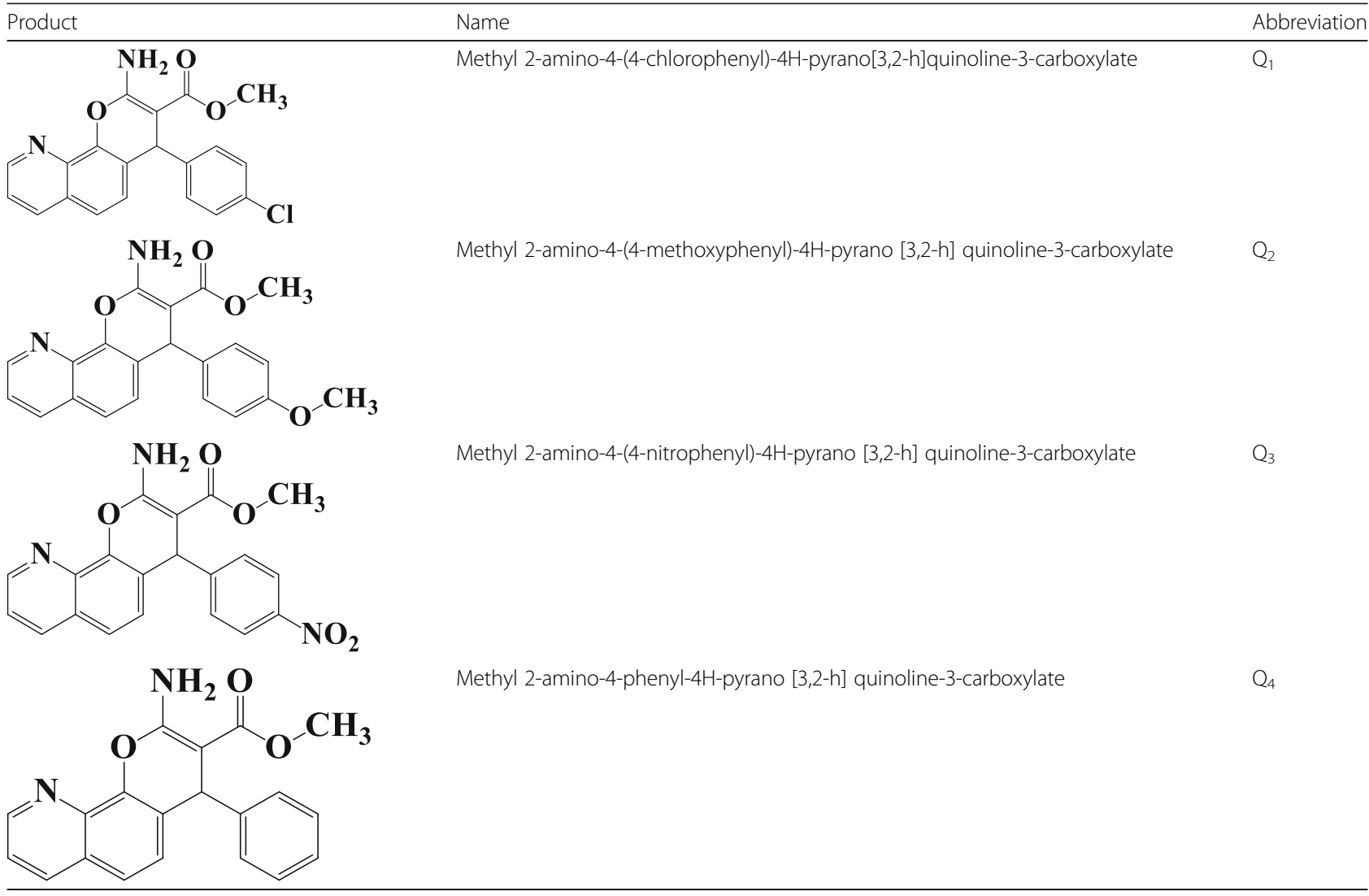


adopting the general procedure: yield 91\%, aspect white solid, $M_{p} 133-135^{\circ} \mathrm{C}, R_{f}$ value 0.78 (n-hexane/ dichloromethane: 5/5, (v/v)).

IR $\left(\mathrm{KBr}\right.$, in $\left.\mathrm{cm}^{-1}\right): 2071.88(\mathrm{C}=\mathrm{N}), 1387.17(\mathrm{C}=\mathrm{C})$, $3444.60\left(\mathrm{NH}_{2}\right), 1606.20(\mathrm{C}=\mathrm{O})$.

${ }^{1} \mathrm{H}\left(300 \mathrm{MHz}, D S M O-d_{6}\right): \delta_{\mathrm{ppm}}=8.73\left(\mathrm{~S}, 2 \mathrm{H}, \mathrm{NH}_{2}\right), 5.62$ $\left(\mathrm{S}, 1 \mathrm{H}, \mathrm{CH}_{\text {pyran }}\right), 3.35\left(\mathrm{CH}_{3}\right), 7.50-7.76-8.05-8.39-8.74(\mathrm{~m}$, $5 \mathrm{H}$, Ar- quinoline), 7.27-7.30-7.58 (m, 4H, benzene ring).

${ }^{13} \mathrm{C}\left(300 \mathrm{MHz}, \mathrm{DSMO}-d_{6}\right): \delta_{\mathrm{ppm}}=47.93\left(\mathrm{CH}_{3}\right), 152.37$ $\left(\mathrm{C}-\mathrm{NH}_{2}\right), 153.74(\mathrm{C}=\mathrm{O}), 111.04-127.94-148.21(\mathrm{ArCH}$ of quinoline), 119.74-122.09-133.27 (ArC of quinoline), 127.73-129.23 ( $\mathrm{ArCH}$ of benzene ring), 139.31 ( $\mathrm{ArC}$ of benzene ring).

\subsubsection{Microanalysis}

Calculated: C, 65.49\%; H, 4.12\%; N, 7.64\%.

Obtained: C, 65.15\%; H, 4.64\%; N, 7.56\%.
4.1.2 Synthesis of methyl 2-amino-4-(4-methoxyphenyl)-4Hpyrano[3,2-h]quinoline-3-carboxylate $\left(Q_{2}\right)$

It was synthesized from 4-methoxybenzaldehyde with methyl 2-cyanoacetate and 8-hydroxyquinoline (8-HQ) adopting the general procedure: yield $81 \%$, aspect yellow solid, $M_{p} 141-143^{\circ} \mathrm{C}, R_{f}$ value 0.90 (n-hexane/dichloromethane: $5 / 5,(\mathrm{v} / \mathrm{v}))$.

IR $\left(\mathrm{KBr}\right.$, in $\left.\mathrm{cm}^{-1}\right): 2686.20(\mathrm{C}=\mathrm{N}), 1469.89(\mathrm{C}=\mathrm{C})$, $3444.60\left(\mathrm{NH}_{2}\right), 1629.08(\mathrm{C}=\mathrm{O})$.

${ }^{1} \mathrm{H}\left(300 \mathrm{MHz}, \mathrm{DSMO}-d_{6}\right): \delta_{\mathrm{ppm}}=8.37\left(\mathrm{~S}, 2 \mathrm{H}, \mathrm{NH}_{2}\right)$, $5.72\left(\mathrm{~S}, 1 \mathrm{H}, \mathrm{CH}_{\text {pyran }}\right), 2.05\left(\mathrm{CH}_{3}\right), 6.71-7.19-7.22-7.60-$ 7.61-8.38 (m, 5H, Ar-quinoline), 7.59-7.22-7.58 (m, $4 \mathrm{H}$, benzene ring).

${ }^{13} \mathrm{C}\left(300 \mathrm{MHz}, \quad D S M O-d_{6}\right): \delta_{\mathrm{ppm}}=57.78\left(\mathrm{CH}_{3}\right)$, $149.16\left(\mathrm{C}-\mathrm{NH}_{2}\right), 150.95(\mathrm{C}=\mathrm{O}), 113.27-114.04-128.86-$ 129.39-146.18 ( $\mathrm{ArCH}$ of quinoline), 122.43-124.72131.03-145.53 (ArC of quinoline), 122.67-128.95

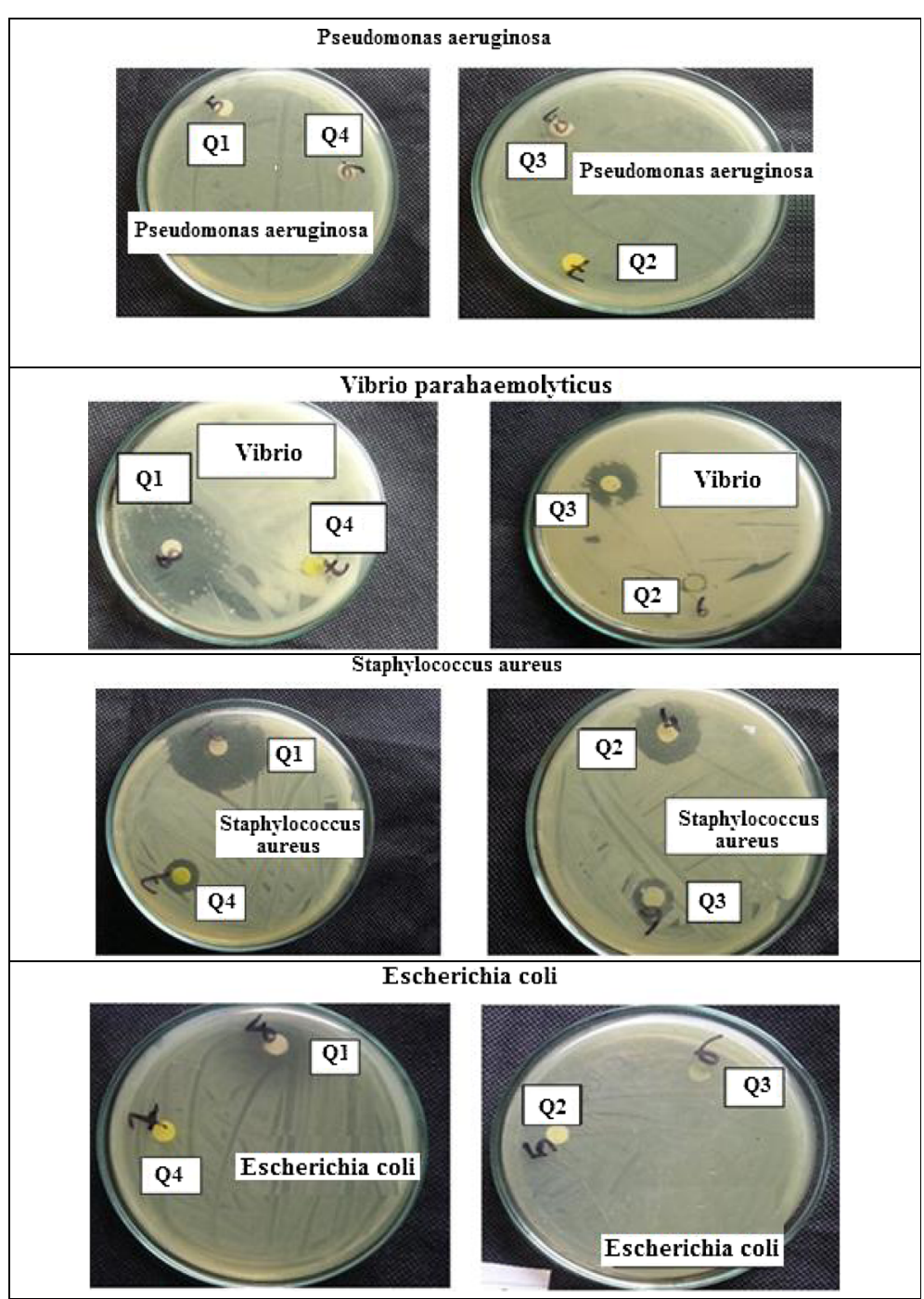

Fig. 2 Antibacterial activity of the pyranoquinoline derivatives against bacteria after $24 \mathrm{~h}$ of incubation at $37^{\circ} \mathrm{C}$ 
(ArC1H of benzene ring), 129.74-129.32 (ArC of benzene ring).

\subsubsection{Microanalysis}

Calculated: C, 69.60\%; H, 5.01\%; N, 7.73\%.

Obtained: C, 69.65\%; H, 5.62\%; N, 7.54\%.

\subsubsection{Synthesis of methyl 2-amino-4-(4-nitrophenyl)-4H- pyrano[3,2-h]quinoline-3-carboxylate $\left(Q_{3}\right)$}

It was synthesized from 4-nitrobenzaldehyde, methyl 2cyanoacetate and 8-hydroxyquinoline (HQ) by adopting the general procedure: yield 93\%, aspect red solid, $M_{p}$ $137-139^{\circ} \mathrm{C}, R_{f}$ value 0.25 (n-hexane/dichloromethane: $5 /$ $5,(\mathrm{v} / \mathrm{v}))$.

IR $\left(\mathrm{KBr}\right.$, in $\left.\mathrm{cm}^{-1}\right): 2382.08(\mathrm{C}=\mathrm{N}), 1400.90(\mathrm{C}=\mathrm{C})$, $3436.18\left(\mathrm{NH}_{2}\right), 1628.16(\mathrm{C}=\mathrm{O})$.

${ }^{1} \mathrm{H}\left(300 \mathrm{MHz}, \mathrm{DSMO}-d_{6}\right): \delta_{\mathrm{ppm}}=8.28\left(\mathrm{~S}, 2 \mathrm{H}, \mathrm{NH}_{2}\right)$, $5.75\left(\mathrm{~S}, 1 \mathrm{H}, \mathrm{CH}_{\text {pyran }}\right), 3.36\left(\mathrm{CH}_{3}\right), 7.20-7.21-7.22-7.60-$ 7.62-7.63 (m, 5H, Ar-quinoline), 7.48-7.49-7.50 (m, 4H, benzene ring).

${ }^{13} \mathrm{C}\left(300 \mathrm{MHz}, \mathrm{DSMO}-d_{6}\right): \delta_{\mathrm{ppm}}=44.88\left(\mathrm{CH}_{3}\right), 153.61$ $\left(\mathrm{C}-\mathrm{NH}_{2}\right), 169.18(\mathrm{C}=\mathrm{O}), 110.34-110.92-127.08-129.14-$ 148.52 (ArCH of quinoline), 121.91-123.48-132.40139.12 (ArC of quinoline), 122.43-127.48 ( $\mathrm{ArCH}$ of benzene ring), 132.02-131.38 (ArC of benzene ring).

\subsubsection{Microanalysis}

Calculated: C, 63.66\%; H, 4.01\%; N, 11.14\%.

Obtained: C, 63.54\%; H, 4.16\%; N, 11.78\%.
4.1.4 Synthesis of methyl 2-amino-4-phenyl-4H-pyrano[3,2h]quinoline-3-carboxylate $\left(Q_{4}\right)$

It was synthesized from benzaldehyde with methyl 2cyanoacetate and 8-hydroxyquinoline (HQ) according to the general procedure: yield $92 \%$, aspect white solid, $M_{p} 147-149^{\circ} \mathrm{C}, R_{f}$ value 0.76 (n-hexane/dichloromethane: $5 / 5,(\mathrm{v} / \mathrm{v}))$.

IR $\left(\mathrm{KBr}\right.$, in $\left.\mathrm{cm}^{-1}\right): 2022.38(\mathrm{C}=\mathrm{N}), 1636.29(\mathrm{C}=\mathrm{C})$, $3496.01\left(\mathrm{NH}_{2}\right), 1387.48(\mathrm{C}=\mathrm{O})$.

${ }^{1} \mathrm{H}\left(300 \mathrm{MHz}, \mathrm{DSMO}-d_{6}\right): \delta_{\mathrm{ppm}}=8.21\left(\mathrm{~S}, 2 \mathrm{H}, \mathrm{NH}_{2}\right)$, $3.33\left(\mathrm{~S}, 3 \mathrm{H}, \mathrm{CH}_{3}\right), 5.69\left(\mathrm{~S}, 1 \mathrm{H}, \mathrm{CH}_{\text {pyran }}\right), 7.50-7.56-7.85-$ 7.92-8.55 (m, 5H, Ar- quinoline), 7.22-7.24-7.34 (m, 5H, benzene ring).

$\left.{ }^{13} \mathrm{C}(300 \mathrm{MHz}, \quad \text { DSMO-d })_{6}\right): \delta_{\mathrm{ppm}}=21.17\left(\mathrm{CH}_{3}\right)$, $164.15\left(\mathrm{C}-\mathrm{NH}_{2}\right), 114.88-127.80-148.34$ (ArCH of quinoline), 115.41-117.56-138.19 (ArC of quinoline), 127.21-129.28 ( $\mathrm{ArCH}$ of benzene ring), 139.12 ( $\mathrm{ArC}$ of benzene ring).

\subsubsection{Microanalysis}

Calculated: C, 72.28\%; H, 4.85\%; N, 8.43\%.

Obtained: C, 72.87\%; H, 4.77\%; N, 8.66\%.

\subsection{Antibacterial test}

The synthesized products were evaluated and screened in vitro for their antibacterial activity on four bacterial strains. The bacterial growth inhibition results are recorded in Figs. 2, 3 and Table 3.

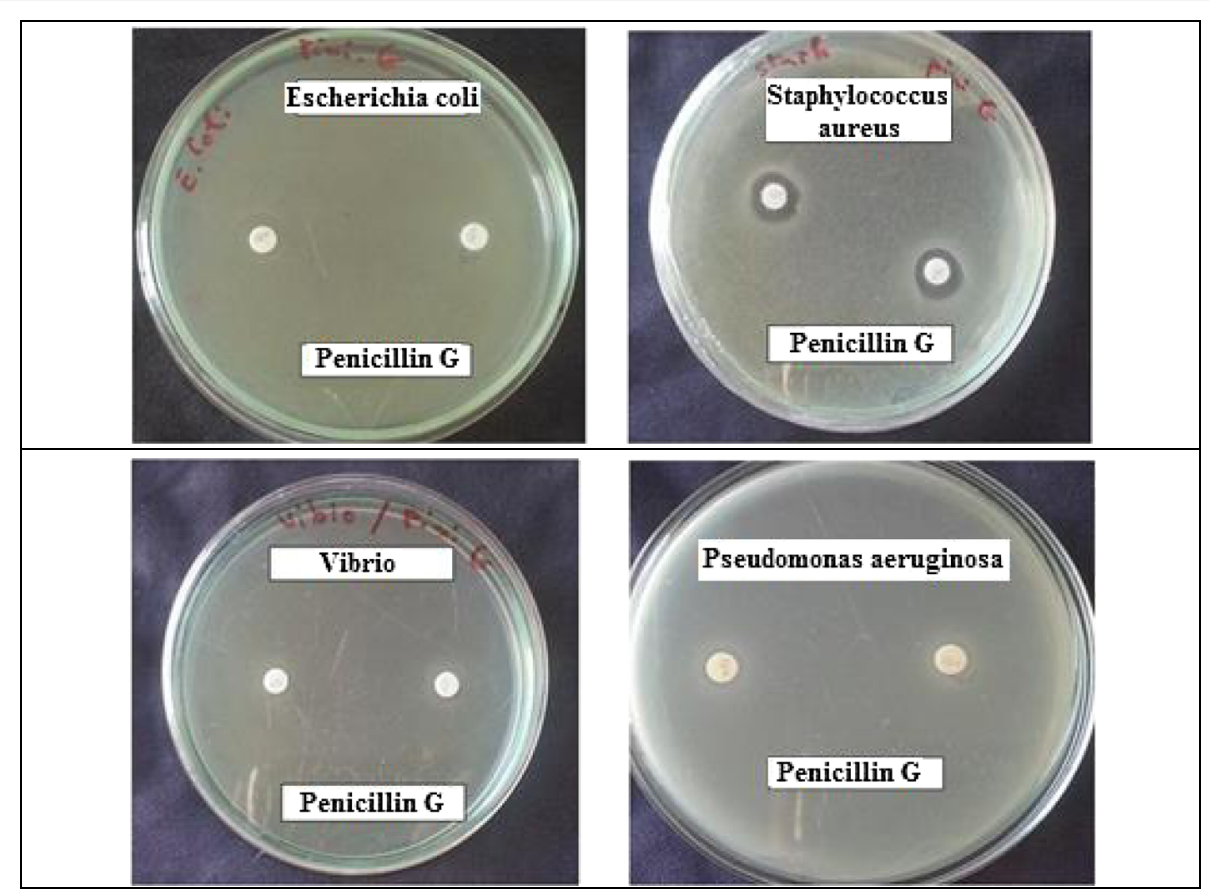

Fig. 3 The antibacterial activity of penicillin $\mathrm{G}$ against bacteria after $24 \mathrm{~h}$ of incubation at $37^{\circ} \mathrm{C}$ 
Table 3 Inhibition zone (in $\mathrm{mm}$ ) of the synthesized compounds compared with standard antibiotic penicillin G against Gram-positive and Gram-negative bacteria at $10^{-3} \mathrm{~g} / \mathrm{ml}$

\begin{tabular}{|c|c|c|c|c|}
\hline \multirow[t]{3}{*}{ Compound } & \multicolumn{4}{|c|}{ Inhibition zone diameter (mm) } \\
\hline & \multicolumn{2}{|l|}{ Gram-positive bacteria } & \multicolumn{2}{|c|}{ Gram-negative bacteria } \\
\hline & Staphylococcus aureus & Vibrio parahaemolyticus & Escherichia coli & Pseudomonas aeruginosa \\
\hline $\mathrm{Q}_{1}(R=\mathrm{Cl})$ & 35 & 30 & 18 & - \\
\hline $\mathrm{Q}_{2}\left(R=\mathrm{OCH}_{3}\right)$ & 17 & 10 & - & - \\
\hline $\mathrm{Q}_{3}\left(R=\mathrm{NO}_{2}\right)$ & 13 & 10 & - & - \\
\hline $\mathrm{Q}_{4}(R=\mathrm{H})$ & 11 & 5 & - & - \\
\hline Penicillin G & 11 & 5 & 10 & 9 \\
\hline
\end{tabular}

\section{Discussion}

All the tested compounds $\mathrm{Q}_{1}, \mathrm{Q}_{2}, \mathrm{Q}_{3}$, and $\mathrm{Q}_{4}$ show outstanding antibacterial activity against Gram-positive and Gram-negative strains compared to the standard antibiotic (penicillin G). This activity is higher against Gram-positive bacteria than Gram-negative bacteria. We note that for the strain Pseudomonas aeruginosa (ATCC 27853) all these compounds have no effect. According to the literature, these poor results against Gram-negative bacteria can be explained by the presence of another membrane which reduces the transfer of the compounds $\mathrm{Q}_{1}, \mathrm{Q}_{2}, \mathrm{Q}_{3}$, and $\mathrm{Q}_{4}$ through the cytoplasmic membrane, these results are in agreement with those of Himmi et al. [14], who showed that in vitro 8-hydroxyquinoline derivatives were more active against Gram-positive bacteria Staphylococcus aureus (ATCC 6538), Bacillus subtilis (ATCC6633), Escherichia coli (ATCC 8739), and Gramnegative Pseudomonas aeruginosa (CIP 82118) and Clostridium sporogenes (ATCC 31793).

The results obtained in the present work show that the tested compounds have a remarkable inhibitory effect on the growth of the majority of bacterial strains tested. These observed antibacterial activities are also explained by the presence of the quinoline nucleus, which has already shown an antibacterial effect in other research work [15].

Therefore, in order to improve the antibacterial activity of our compounds, we have bound the quinoline ring with a pyranic ring and a benzene ring bearing electrondonor substituents such as $-\mathrm{Cl},-\mathrm{OCH}_{3}$, and $-\mathrm{OC}_{2} \mathrm{H}_{5}$. Furthermore, it has been shown that heterocyclic compounds bearing electron-withdrawing substituents (nitro, acid function, etc.) have shown lower antimicrobial activity against Gram-positive and Gram-negative bacteria than compounds carrying electron-donor substituents such as $O$-alkyl, $O$-aryl, and chlorophenyl [16]. In our study, we note that compounds bearing electron-donor substituents on the benzene ring linked to the pyranic nucleus exert a positive antimicrobial activity against some Gram-positive and Gram-negative bacteria such as Staphylococcus aureus, Vibrio parahaemolyticus, and Escherichia coli.

\section{Conclusion}

The analysis of the results obtained by the diffusion method of the disc shows that the compound whose benzene nucleus bears chlorine is therefore the most active compared to the other compounds and also compared to the blank of penicillin G. The antibacterial activity of the chlorinated compound is more important against Gram-positive bacteria than Gram-negative bacteria such as the Staphylococcus aureus strain which is the most sensitive.

\section{Additional file}

Additional file 1: Spectral data of the synthetized compounds. (DOCX $1047 \mathrm{~kb})$

\section{Acknowledgements}

The authors acknowledge the infrastructure and support of the "Ibn Tofail University" and the "National Center for Scientific and Technical Research".

\section{Authors' contributions}

MR contributed in the synthesis of the tested compounds and identifying their structures, participated in the antibacterial activity evaluation, and wrote the manuscript. $\mathrm{AH}$ contributed in the evaluation of the antibacterial activities. OB performed the antibacterial tests. $Y L$ participated in the preparation of the manuscript and the verification of the English language. $\mathrm{KO}$ contributed in the conception and verification of the biological part. BL contributed in the design of the organic synthesis part, manuscript preparation, and the verification of the English language. All authors read and approved the final manuscript.

\section{Funding}

This work is supported in part by the "Ibn Tofail University" and "National Center for Scientific and Technical Research"

\section{Availability of data and materials}

Data sharing is not applicable to this article as no datasets were generated or analyzed during the current study.

Ethics approval and consent to participate

Not applicable.

Consent for publication

Not applicable.

Competing interests

The authors declare that they have no competing interests. 


\section{Author details}

'Laboratory of Agro-resources, Polymers and Process Engineering, Department of Chemistry, Faculty of Sciences, Ibn Tofail University, PO Box 133, 14000 Kenitra, Morocco. ${ }^{2}$ Laboratory of Nutrition, Health and Environment, Department of Biology, Faculty of Sciences, Ibn Tofail University, PO Box 133, 14000 Kenitra, Morocco.

Received: 28 June 2019 Accepted: 1 August 2019

Published online: 12 September 2019

\section{References}

1. Oremland RS, Stolz JF (2005) Arsenic, microbes and contaminated aquifers. Trends Microbiol 13:45-49. https://doi.org/10.1016/j.tim.2004.12.002

2. Sands P, El Turabi A, Saynisch PA, Dzau VJ (2016) Assessment of economic vulnerability to infectious disease crises. The Lancet 388:2443-2448. https:// doi.org/10.1016/S0140-6736(16)30594-3

3. Schwartz T, Kohnen W, Jansen B, Obst U (2003). Detection of antibioticresistant bacteria and their resistance genes in wastewater, surface water, and drinking water biofilms. FEMS Microbiol Ecol 43:325-335

4. Vlietinck AJ, Berghe DAV (1991) Can ethnopharmacology contribute to the development of antiviral drugs. J Ethnopharmacol 32:141-153. https://doi. org/10.1016/0378-8741(91)90112-Q

5. Lee VJ, Hecker SJ (1999) Antibiotic resistance versus small molecules, the chemical evolution. Med Res Rev 19:521-542

6. Ballardini R, Varani G, Indelli MT, Scandola F (1986) Phosphorescent 8quinolinol metal chelates. Excited-state properties and redox behaviour. Inorg Chem 25:3858-3865. https://doi.org/10.1021/ic00242a006

7. Shen AY, Chen CP, Roffler S, (1999) A chelating agent possessing cytotoxicity and antimicrobial activity: 7-morpholinomethyl-8-hydroxyquinoline. Life sciences 64:813-825

8. Adlard PA, Cherny RA, Finkelstein DI, Gautier E, Robb E, Cortes M, Laughton K (2008) Rapid restoration of cognition in Alzheimer's transgenic mice with 8-hydroxy quinoline analogs is associated with decreased interstitial $A \beta$. Neuron 59:43-55. https://doi.org/10.1016/j.neuron.2008.06.018

9. Rbaa M, Bazdi O, Lakhrissi Y, Ounine K, Lakhrissi B (2018) Synthesis, Characterization and Biological Activity of new Pyran Derivatives of 8 Hydroxyquinoline. Eurasian J Anal Chem 13:19-30

10. Reitz RD, Duraisamy G (2015) Review of high efficiency and clean reactivity controlled compression ignition (RCCl) combustion in internal combustion engines. Prog. Energy Combust. Sci 46:12-71. https://doi.org/10.1016/j. pecs.2014.05.003

11. Klevens RM, Morrison MA, Nadle J, Petit S, Gershman K, Ray S, Craig AS (2007) Infections invasives a Staphylococcus aureus resistant à la methicilline aux Etats-Unis. JAMA-français 298:1763-1771

12. Lodise Jr, TP, Lomaestro B, Drusano GL (2007) Piperacillin-tazobactam for Pseudomonas aeruginosa infection: clinical implications of an extendedinfusion dosing strategy. Clin Infect Dis 44:357-363. https://doi.org/10.1 086/510590

13. Elmahdi S, DaSilva LV, Parveen S (2016) Antibiotic resistance of Vibrio parahaemolyticus and Vibrio vulnificus in various countries: A review Food Microbiol 57:128-134. https://doi.org/10.1016/j.fm.2016.02.008

14. Himmi B, Kitane S, Eddaif A, Joly JP, Hlimi F, Soufiaoui M, Sebban A (2008) Synthesis of novel 5,7-disubstituted 8-hydroxyquinolines. J Heterocycl Chem 45:1023-1026. https://doi.org/10.1002/jhet.5570450411

15. Cherdtrakulkiat R, Boonpangrak S, Sinthupoom N, Prachayasittikul S, Ruchirawat S, Prachayasittikul V (2016) Derivatives (halogen, nitro and amino) of 8-hydroxyquinoline with highly potent antimicrobial and antioxidant activities. Biochem Biophys Rep 6:135-141. https://doi.org/10.1 016/j.bbrep.2016.03.014

16. Elassar A Z A, Elkholy Y M, Elnagdi MH (1998) Chemistry of Crotononitrile. J. Prakt. Chem 6:491-505. https://doi.org/10.1002/prac.19983400602

\section{Publisher's Note}

Springer Nature remains neutral with regard to jurisdictional claims in published maps and institutional affiliations.

\section{Submit your manuscript to a SpringerOpen ${ }^{\circ}$ journal and benefit from:}

- Convenient online submission

- Rigorous peer review

- Open access: articles freely available online

- High visibility within the field

- Retaining the copyright to your article

Submit your next manuscript at $\boldsymbol{\nabla}$ springeropen.com 